\title{
Fungi Associated with Postharvest Diseases of Sweet Potato Storage Roots and In Vitro Antagonistic Assay of Trichoderma harzianum against the Diseases
}

\author{
Narayan Chandra Paul ${ }^{1,2}{ }^{\mathbb{D}}$, Soyoon Park ${ }^{1}$, Haifeng Liu ${ }^{1}$, Ju Gyeong Lee ${ }^{1}$, Gui Hwan Han ${ }^{3}$, Hyunsook Kim ${ }^{4}$ and \\ Hyunkyu Sang 1,2,*(D) \\ 1 Department of Integrative Food, Bioscience and Biotechnology, Chonnam National University, \\ Gwangju 61186, Korea; ncpaulcnu@gmail.com (N.C.P.); psyangel0522@gmail.com (S.P.); \\ liuhaifeng141@gmail.com (H.L.); wnrud2338@gmail.com (J.G.L.) \\ 2 Kumho Life Science Laboratory, Chonnam National University, Gwangju 61186, Korea \\ 3 Center for Industrialization of Agricultural and Livestock Microorganisms, Jeongeup-si 56212, Korea; \\ ghhan@cialm.or.kr \\ 4 Boran Pharma, Seoul 04206, Korea; kimhs@glovax.com \\ * Correspondence: hksang@jnu.ac.kr
}

Citation: Paul, N.C.; Park, S.; Liu, H.; Lee, J.G.; Han, G.H.; Kim, H.; Sang, H. Fungi Associated with Postharvest Diseases of Sweet Potato Storage Roots and In Vitro Antagonistic Assay of Trichoderma harzianum against the Diseases. J. Fungi 2021, 7, 927. https://doi.org/10.3390/jof7110927

Academic Editor: Paloma Melgarejo

Received: 23 September 2021

Accepted: 26 October 2021

Published: 31 October 2021

Publisher's Note: MDPI stays neutral with regard to jurisdictional claims in published maps and institutional affiliations.

Copyright: (c) 2021 by the authors. Licensee MDPI, Basel, Switzerland. This article is an open access article distributed under the terms and conditions of the Creative Commons Attribution (CC BY) license (https:/ / creativecommons.org/licenses/by/ $4.0 /)$.

\begin{abstract}
Sweet potato is the 11th most important food crop in the world and an excellent source of nutrition. Postharvest diseases were monitored in sweet potato storage roots collected from the local markets in Korea during 2021. Several diseases including Fusarium surface and root rot, charcoal rot, dry rot, and soft rot were observed in the postharvest sweet potatoes. A total of 68 fungal isolates were obtained from the diseased samples, and the isolates were grouped into 8 different fungal colony types. Based on multilocus phylogeny and morphological analysis of 17 representative isolates, the isolates were identified as Fusarium oxysporum, F. ipomoeae, F. solani, Penicillium citrinum, P. rotoruae, Aspergillus wentii, Mucor variicolumellatus (Mu. circinelloides species complex), and Macrophomina phaseolina. F. oxysporum was the predominant pathogen as this is the most common pathogen of sweet potato storage roots causing the surface rot disease, and M. phaseolina caused the most severe disease among the pathogens. Dual culture antagonistic assays were evaluated using Trichoderma harzianum strains CMML20-26 and CMML20-27. The results revealed that the two strains showed strong antifungal activity in different ranges against all tested pathogens. This study provides an understanding of diverse postharvest diseases in sweet potatoes and suggests potential biocontrol agents to manage the diseases. In addition, this is the first report of sweet potato storage root rot diseases caused by $A$. wentii, and P. rotoruae worldwide.
\end{abstract}

Keywords: fungal pathogens; postharvest disease; sweet potato; storage root; Penicillium rotoruae; Aspergillus wentii

\section{Introduction}

The sweet potato (Ipomoea batatas (L.) Lam.; Convolvulaceae) is regarded as one of the most important food crops in the world and is an alternative source of bioenergy, with an annual production area of 8.0 million hectares and a total global production of 106,569 million tons [1,2]. Its storage roots and leaves can be used as a staple food, animal feed, and supplementary food such as chips and starch production $[3,4]$. Therefore, this crop is now regarded as a high-priority crop targeted for reducing food insecurity and malnutrition in many countries [5]. Furthermore, sweet potato is an excellent source of nutrients, including vitamins, potassium, iron, calcium, and minerals with medicinal value owing to its anti-cancer, anti-diabetic, and anti-inflammatory activities [6-10]. Additionally, functional food products, such as $\beta$-carotene and anthocyanins, come from sweet potato, making it a source of novel natural health-promoting compounds [8]. 
There are several biotic and abiotic factors limiting the production and commercialization of sweet potatoes. Among them, fungal diseases are the most prominent before and after harvest; fungi reduce the quality of storage roots [11,12]. The periderm of the sweet potato is thinner, increasing the risk of storage diseases and causing severe losses during storage [12,13]. Moreover, the presence of postharvest pathogens affects both the appearance and taste of the products [14]. Commonly observed postharvest diseases caused by fungi include black rot (Ceratocystis fimbriata), dry rot (A. niger and Diaporthe batatas), Fusarium surface rot (F. oxysporum), Fusarium root and end rot (F. solani), foot rot (Plenodomus destruens), soft rot (Rhizopus stolonifer and Rhizopus oryzae), blue mold (Penicillium spp.), java black rot (Botryodiplodia theobromae), circular spot (Sclerotium rolfsii), charcoal $\operatorname{rot}$ (M. phaseolina), and storage $\operatorname{rot}$ (Mucor sp.) [3,5,6,10,13-18]. Some pathogens such as Fusarium spp. and M. phaseolina can survive in crop residue and soil from one season to another and enter the storage roots through wounding, causing diseases postharvest [5]. Other high decay losses result from tip rot, which is characterized by visible decay at one or both ends of the storage roots. The types of pathogens involved in tip decay have been inconsistent; common pathogens isolated include F. solani, M. phaseolina, B. theobromae, and D. batatas $[5,19,20]$.

Cultural practices are generally applied to overcome or minimize the problems associated with the storage of sweet potatoes. In addition, chemicals can also be applied to remove pathogens from storage roots [21,22]. However, it is believed that chemical applications threaten the quality and safety of food. In agriculture, farmers rely heavily on synthetic fungicides or pesticides to successfully control plant diseases. However, the environmental pollution caused by excessive use of agrochemicals is of worldwide concern. Therefore, development of alternative methods is actively being researched, such as microbially sourced antifungal agents and chemicals [21,23].

In the present study, sweet potato samples were collected from the local markets of three locations in Korea, and different symptoms of postharvest diseases were observed. Therefore, this study aimed (i) to investigate the postharvest fungal diseases of sweet potato in Korea and characterize the causal fungal isolates by molecular phylogenetic and morphological analyses and pathogenicity assay, and (ii) to test in vitro biocontrol activity against the fungal pathogens by two T. harzianum strains.

\section{Materials and Methods}

\subsection{Fungal Isolation}

Sweet potato storage root samples were collected from the market of three different locations in Korea in 2021, and the locations were Buan-gun, Cheonan-si, and Haenamgun. Samples were kept in polyethylene bags, brought to the laboratory, and stored in a refrigerator prior to isolation of pathogens. For the isolation, diseased storage roots were surface sterilized with $1 \% \mathrm{NaOCl}$ solution for $5 \mathrm{~min}$, washed three times with sterilized distilled water, and then air-dried on filter paper in a laminar airflow chamber. The storage roots were placed onto potato dextrose agar (PDA) supplemented with $50 \mu \mathrm{g} \mathrm{mL}^{-1}$ of streptomycin, rifampicin, and kanamycin (MB cell, Seoul, Korea) to stop bacterial growth. After incubation at $25^{\circ} \mathrm{C}$ for 3-10 days, individual hyphal tips of the developing fungal colonies were placed onto PDA and further incubated for 5-10 days for culture purity. Finally, representative isolates were selected, assigned an identification number (CMML21-1 to CMML21-17), and preserved in the Molecular Microbiology Lab, Dept. of Integrative Food, Bioscience and Biotechnology, Chonnam National University, Gwangju, Republic of Korea (Table S1). The fungal isolates were preserved in $20 \%$ glycerol stock solution at $-80^{\circ} \mathrm{C}$. The photographs of symptomatic sweet potato postharvest diseases and fungal colonies grown from the surface sterilized storage roots are shown in Figure 1. 

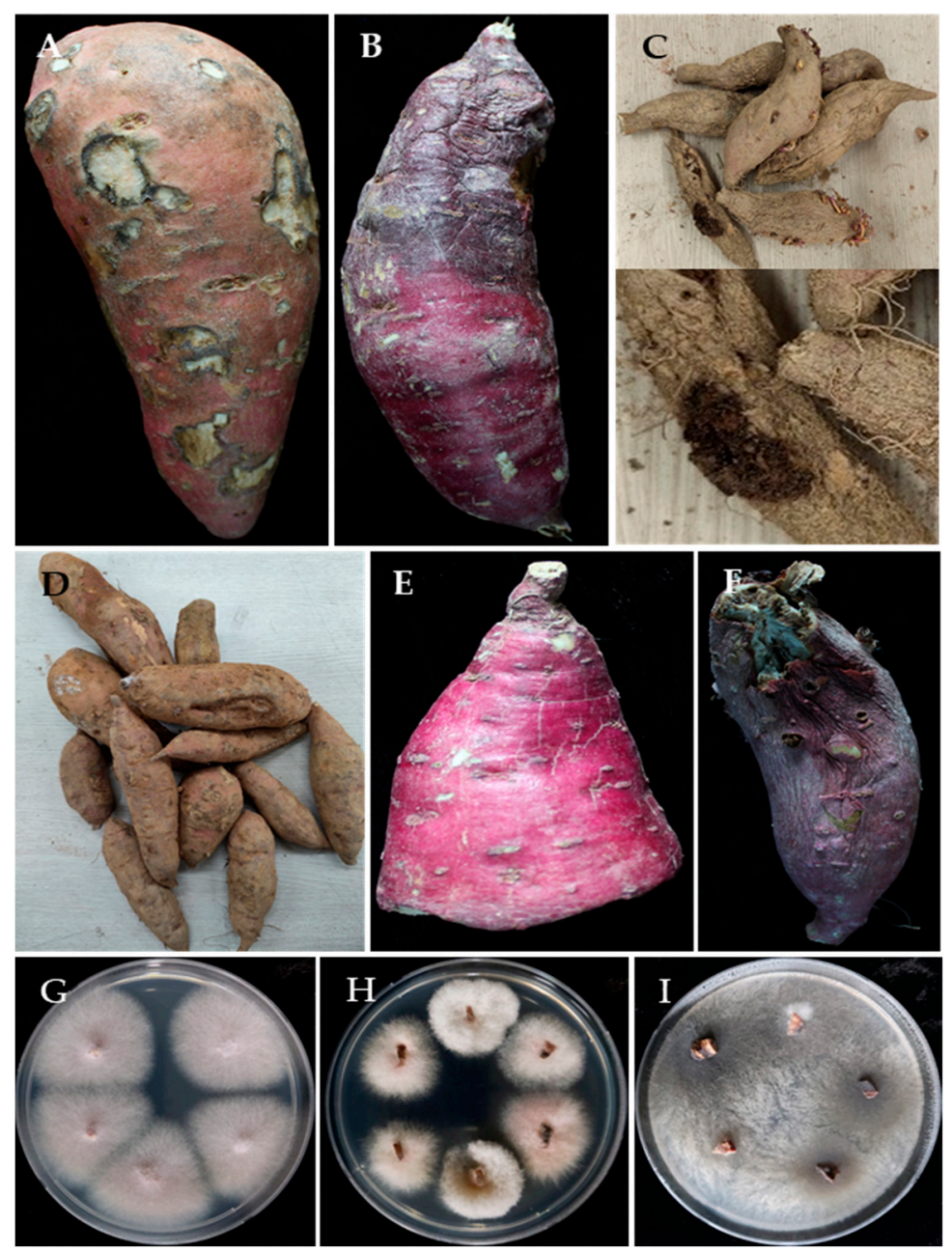

Figure 1. Symptoms of sweet potato postharvest diseases collected from local markets in Korea: (A) Fusarium surface rot, (B) charcoal rot, (C) Aspergillus mold, (D) surface rot, (E) end rot, and (F) Penicillium mold. The surface sterilized storage root tissues of Fusarium rot, charcoal rot, and other diseases were placed on potato dextrose agar media containing antibiotics. Examples of fungal colonies grown from the tissues of Fusarium $\operatorname{rot}(\mathbf{G}, \mathbf{H})$ and charcoal $\operatorname{rot}(\mathbf{I})$ are shown.

\subsection{DNA Extraction, PCR Amplification, and Sequencing}

To confirm the identity of the fungi, total genomic DNA was extracted directly from the mycelia grown on PDA using the CTAB DNA-extraction method [24]. Different gene regions, the internal transcribed spacer (ITS), elongation factor 1-alpha (EF1- $\alpha)$, calmodulin (CAL), RNA polymerase II second largest subunit (RPB2), small subunit (SSU, large subunit (LSU), and $\beta$-tubulin (BT) genes were amplified using the primer pairs ITS1-ITS4, EF1 728F-EF1 986R, CAL1-CAL2, RPB2 5F-RPB2 7cR, NS1-NS4, LROR-LR5, and B27a-B27b, respectively $[25,26]$. PCR primers were chosen based on fungal genera. For the identification of Fusarium spp. and Macrophomina spp., primers of ITS and EF1- $\alpha$ regions were commonly used. Primers of ITS, SSU, and LSU regions were chosen for the identification of Mucor spp. To identify species level of Aspergillus and Penicillium, primer sets from ITS, BT, CAL, and RPB2 were used. The polymerase chain reaction (PCR) was carried out using a SimpliAmp ${ }^{\text {TM }}$ PCR system by Applied biosystems ${ }^{\circledR}$ (Thermofisher Scientific, MA, USA) in a $25 \mu \mathrm{L}$ reaction volume containing $0.25 \mu \mathrm{L}$ of Takara Ex Taq ${ }^{\circledR}$ DNA polymerase (TaKaRa Bio Inc., Shiga, Japan) $\left(5 \mathrm{U} \mu \mathrm{L}^{-1}\right), 2.5 \mu \mathrm{L}$ of $10 \times$ Ex Taq buffer, $2 \mu \mathrm{L}$ of dNTP mixture ( $2.5 \mathrm{mM}$ each), $1 \mu \mathrm{L}$ of each primer (10 pmoles $\left.\mu \mathrm{L}^{-1}\right), 1 \mu \mathrm{L}$ template DNA solution $\left(100 \mathrm{ng} \mu \mathrm{L}^{-1}\right)$, and sterilized distilled water up to $25 \mu \mathrm{L}$. The PCR amplification conditions were initial denaturation at $98^{\circ} \mathrm{C}$ for $30 \mathrm{~s}$, followed by 35 cycles of denaturation at $98^{\circ} \mathrm{C}$ 
for $15 \mathrm{~s}$, and annealing at $50{ }^{\circ} \mathrm{C}$ for ITS, SSU and LSU, $55^{\circ} \mathrm{C}$ for EF1- $\alpha$ and CAL, $49{ }^{\circ} \mathrm{C}$ for RPB2, $52{ }^{\circ} \mathrm{C}$ for BT, with $30 \mathrm{~s}$, and a final extension at $72{ }^{\circ} \mathrm{C}$ for $2 \mathrm{~min}$. PCR products were sequenced in both directions by a commercial sequencing service provider (Macrogen, Daejeon, Korea).

\subsection{Molecular Phylogeny}

Sequences were manually adjusted with a MEGA X program [27] and subjected to Basic Local Alignment Search Tool (BLASTN) searches using the National Center for Biotechnology Information (NCBI) database (http:/ / www.ncbi.nlm.nih.gov) to obtain sequence similarity. Closely related sequences were obtained from GenBank (Table S2) for phylogenetic analysis, adjusted manually using the MEGA X program [27], and aligned using ClustalX v1.83 [28]. The sequence ends were trimmed manually to remove lowquality bases using the BioEdit v5.0.9.1 program [29]. Maximum likelihood (ML) analysis was performed using the MEGA X program [27] to construct phylogenetic trees.

\subsection{Morphology}

To determine colony morphology, representative isolates were cultured on different media depending on the fungal genera, including potato dextrose agar (PDA), malt extract agar (MEA), Czapek yeast extract agar (CYA), and yeast extract sucrose agar (YES) at $25{ }^{\circ} \mathrm{C}$ in the dark for 7 days. To microscopically observe the conidia, mycelia of the isolates were scratched off after 7 days and incubated under NUV (near-ultraviolet) light in 12h-12h light-dark conditions for 3-5 days [30]. The size and shape of the conidia, conidiophores and other morphological characteristics were measured using a microscope (Olympus, Tokyo, Japan). Color names were assigned using 'A Morphological Colour Chart' [31]. Morphological characteristics of the isolates were then compared with previous descriptions.

\subsection{Pathogenicity and Reisolation}

Pathogenicity assay was performed on a susceptible sweet potato variety, namely Beniharuka, with the isolates CMML21-2, CMML21-4, CMML21-5, CMML21-7, CMML218, CMML21-12, CMML21-13, CMML21-16, and CMML21-17. Each isolate was selected from each species group, and two of the isolates (CMML21-4 and CMML21-7) had not previously been identified in sweet potatoes anywhere in the world. Beniharuka is known to be susceptible to common sweet potato diseases. To perform the pathogenicity test, the fungal isolates were cultured on PDA for 7-10 days, and PDA plugs were used to inoculate sweet potato storage roots. The sweet potato storage roots were surface sterilized by dipping in $1 \% \mathrm{NaOCl}$ for $10 \mathrm{~min}$ and washed with sterilized distilled water three times. The storage roots were then allowed to dry in a laminar airflow chamber. A $5 \mathrm{~mm}$ hyphal disc of each isolate was placed in a wound made in each root using a $5 \mathrm{~mm}$ cork borer. Blank PDA discs were used as control treatments [15]. Additionally, the spore suspension method was applied for the newly detected sweet potato pathogens. Sporulation was observed after culturing in PDA for 5-7 days; spores were collected and counted with a hemocytometer. Spore suspensions $(20 \mu \mathrm{L})$ of the Penicillium and Aspergillus isolates were inoculated following the methods described by Paul et al. [10]. Spore suspensions were adjusted to $1 \times 10^{5}$ spores $\mathrm{mL}^{-1}$ before inoculation. Identical amounts of sterilized distilled water served as the control. The storage roots were then kept in moistened clean boxes and incubated at $25^{\circ} \mathrm{C}$. The pathogenicity test was conducted at three different times with three replications each time. After one week of incubation, the artificially inoculated storage roots were observed for lesion development daily; after 3 weeks, pathogenicity was confirmed, and disease severity was measured. Diseased storage roots were used for the reisolation of the fungi on PDA media. After reisolating, the fungal morphology was observed to confirm Koch's postulates. 


\subsection{In Vitro Biocontrol Activity}

Pathogens causing postharvest diseases of sweet potatoes were screened for antifungal activity with two antagonistic Trichoderma harzianum strains (CMML20-26 and CMML20-27) collected from the Molecular Microbiology Laboratory, Dept. of Integrative Food Bioscience and Biotechnology, Chonnam National University, Gwangju, Republic of Korea. Nine representative pathogenic species were selected for screening: F. oxysporum CMML21-2, A. wentii CMML21-4, P. expansum CMML21-5, P. rotoruae CMML21-7, F. ipomoeae CMML21-8, Mu. variicolumellatus CMML21-12, F. oxysporum CMML21-13, M. phaseolina CMML21-16, and F. solani CMML21-17. Five to seven days old antagonistic T. harzianum strains and pathogenic fungi were cultured on opposite edges of the PDA and incubated at $25^{\circ} \mathrm{C}$ for 5-7 days. Each experiment was repeated three times. Antifungal activity was assessed by the size (diameter in $\mathrm{mm}$ ) of the inhibition zones by following the formula explained by Ji et al. [23].

$$
\text { Inhibition percentage }(\%)=\frac{A 1-A 2}{A 1} \times 100
$$

where, $A 1=$ radial growth of pathogenic mycelia without the $T$. harzianum strain (CMML20-26 or CMML20-27), $A 2$ = radial growth of pathogenic mycelia with the T. harzianum strain.

\section{Results}

\subsection{Associated Pathogenic Fungi}

Symptoms of different diseases were observed on the collected storage roots; surface rot disease was most common, followed by several molds. Other diseases found on the storage roots included dry rot, charcoal rot, and end rot. Surface rot symptom was characterized by its circular, somewhat sunken enlarged spots on the surface of the storage roots. Charcoal rot disease was restricted to part of sweet potato so that one end desiccated, and the other end appeared intact. The symptoms of charcoal rot and end rot were very similar, and two different pathogens were obtained from these symptoms. In blue mold symptom, the bluish-green sporulation was abundantly visible on the surface of the storage roots. Dry rot symptom was also found on the surface of the storage roots and became dried (Figure 1A-F). Sweet potato surface sterilized storage root tissues were plated on PDA to isolate the causal pathogens.

In the present study, a total of 68 fungal isolates were recovered; among them, 23, 25 , and 20 isolates were from storage roots originating from Cheonan-si, Haenam-gun, and Buan-gun regions, respectively. The fungal colonies were compared and a total of 17 representatives were selected for further study based on colony morphology and colony characteristics. Colonies assumed to be Fusarium spp. were the most predominate fungi $(67.6 \%)$ recovered in this experiment, followed by Macrophomina sp. (14.7\%), Penicillium spp. (10.3\%), Aspergillus sp. (5.9\%), and Mucor sp. (1.5\%) (Table 1 and Figure 1).

Table 1. Total number of fungi isolated from postharvest sweet potatoes in Korea during the study in 2021.

\begin{tabular}{cccccc}
\hline \multirow{2}{*}{ Location } & \multicolumn{5}{c}{ Number of Fungi Isolated } \\
\cline { 2 - 6 } & Fusarium spp. & Penicillium spp. & Aspergillus sp. & Mucor sp. & Macrophomina sp. \\
\hline Cheonan-si & 12 & 7 & 4 & - & - \\
Haenam-gun & 24 & - & - & 1 & - \\
Buan-gun & 10 & 7 & - & 1 & 10 \\
No. of fungi & 46 & $(10.3 \%)$ & $(5.9 \%)$ & $(1.5 \%)$ & $(14.7 \%)$ \\
Isolation $(\%)$ & $(67.6 \%)$ & & 68 & & \\
Total & & & & \\
\hline
\end{tabular}




\subsection{Molecular Phylogeny}

Based on BLASTN search analysis and molecular phylogeny, the isolates CMML21-1, CMML21-2, CMML21-10, CMML21-11, CMML21-13, and CMML21-14 were identified as F. oxysporum. Two sequences (ITS and EF1- $\alpha$ ) of these isolates showed $99-100 \%$ sequence similarity with the reference strains (SPL 15020 and SPL 16048), which had previously been reported to be F. oxysporum in sweet potato in Korea [3]. The maximum likelihood phylogenetic tree showed that the six isolates and the reference F. oxysporum strains (CBS 129.24, FS11476a, NRRL:34118, NRRL:38352, SPL 15020, and SPL 16048) were grouped together, with a high bootstrap value (99\%). In addition, isolates CMML21-8 and CMML21-9 were identified as F. ipomoeae, supported by high sequence similarity with the reference F. ipomoeae strains, and they formed a monophyletic group comprising the two isolates and F. ipomoeae strains (CQ1099 and LC12163), with a bootstrap value of $97 \%$. A BLASTN search of ITS and EF1- $\alpha$ sequences from isolate CMML21-17 indicated that the isolate had high sequence similarity (99-100\%) with $F$. solani reference strains, and the isolate was grouped with three F. solani strains with a high bootstrap value (\%) (Figure 2).

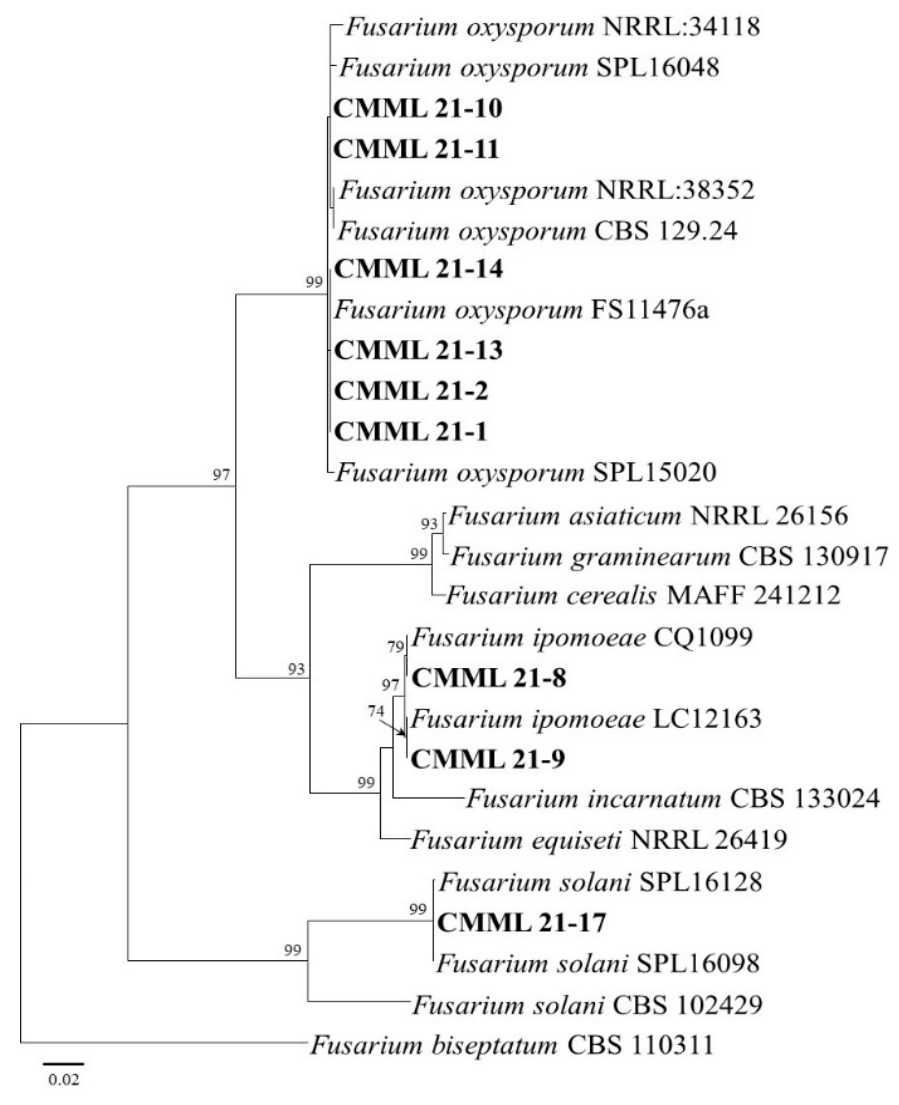

Figure 2. Maximum likelihood tree of the Fusarium isolates (CMML21-1, CMML21-2, CMML21-8, CMML21-9, CMML21-10, CMML21-11, CMML21-13, CMML21-14, and CMML21-17) inferred from the combined data sets of the ITS and EF1- $\alpha$ gene sequences constructed by the MEGA X program. The tree is rooted to F. biseptatum CBS 110311. Numbers on the branches indicate the bootstrap values. The scale bar indicates expected changes per site. The isolates from the present study are indicated in bold.

For the identification of two isolates (CMML21-3 and CMML21-4) of Aspergillus species, three genes, including ITS, BT, and CAL, of isolates were sequenced. BLASTN search analysis and maximum likelihood phylogenetic analysis using three gene sequences (ITS+BT+CAL) revealed that the two isolates matched well with the reference strains (CBS 118.34 and CBS104.07) of $A$. wentii and formed a single clade in the phylogenetic tree with a high bootstrap value (100\%) (Figure 3). 


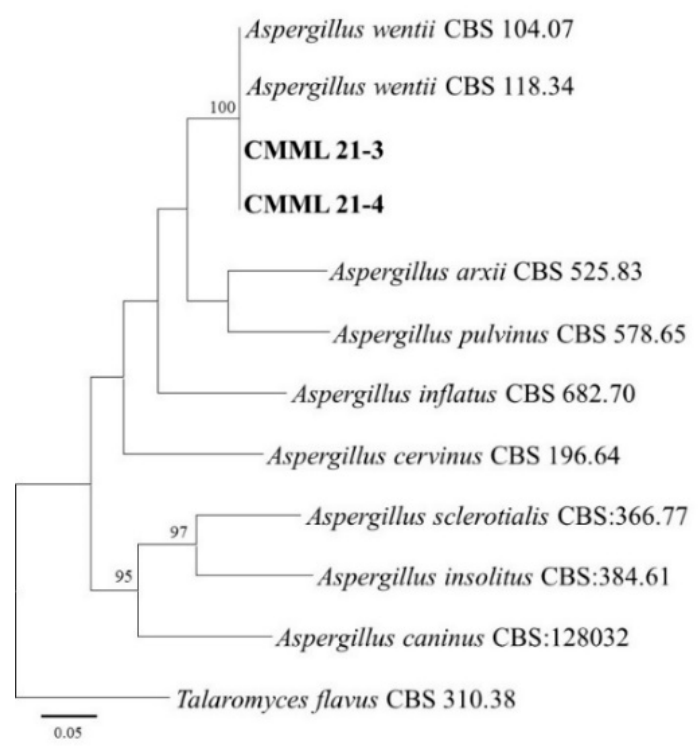

Figure 3. Maximum likelihood tree of the Aspergillus isolates (CMML21-3 and CMML21-4) inferred from the combined data sets of the ITS, BT, and CAL gene sequences constructed by the MEGA $X$ program. The tree is rooted to Talaromyces flavus CBS 310.38. Numbers on the branches indicate the bootstrap values. The scale bar indicates expected changes per site. The isolates from the present study are indicated in bold.

Two morphologically distinct Penicillium species causing mold disease in sweet potatoes were recovered. Isolates CMML21-5 and CMML21-6 were identified as P. citrinum based on a BLASTN search and molecular phylogenetic analyses using multigene sequences (ITS, RPB2, CAL, and BT). The two isolates and three reference $P$. citrinum strains (CBS 139.45, JCM 22607, and DSM 1997) were grouped with a high bootstrap value (100\%). In addition, isolate CMML21-7 was identified as $P$. rotoruae, supported by the high sequence similarity with the $P$. rotoruae strain CBS 14.534 and forming a monophyletic group comprising the isolate and $P$. rotoruae strain, with a bootstrap value of $99 \%$ (Figure 4).

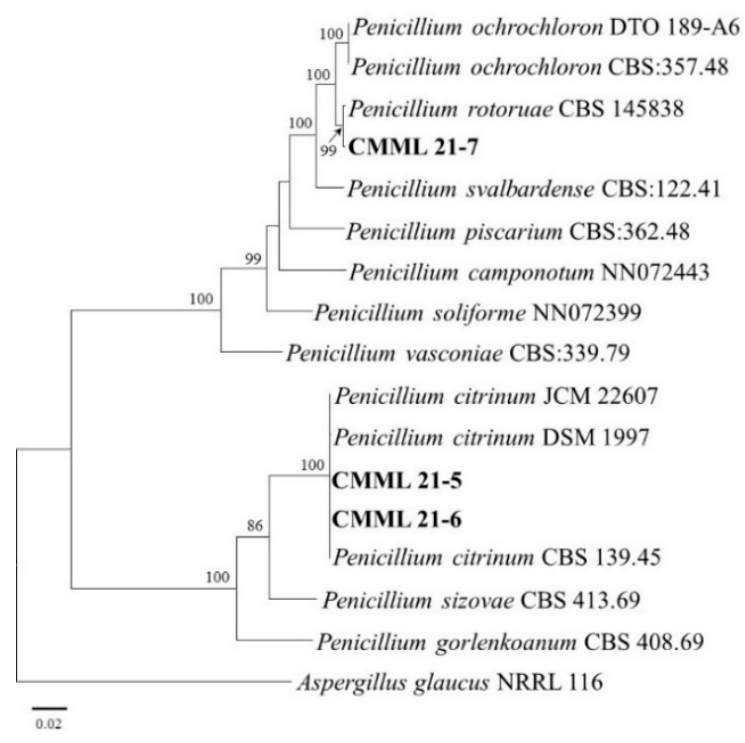

Figure 4. Maximum likelihood tree of the Penicillium isolates (CMML21-5, CMML21-6, and CMML21-7) constructed from the combined data sets of the ITS, RPB2, CAL, and BT gene sequences constructed by the MEGA X program. The tree is rooted to Aspergillus glaucus NRRL 116. Numbers on the branches indicate the bootstrap values. The scale bar indicates expected changes per site. The isolates from the present study are indicated in bold. 
The isolate CMML21-12 obtained from soft rot-related disease in sweet potato was identified as $M u$. variicolumellatus ( $M u$. circinelloides complex). Molecular phylogeny and the maximum likelihood tree constructed from the ITS, SSU, and LSU sequences showed that the isolate matched well with the reference strain of $M u$. variicolumellatus (CBS 236.35) and was closely related to $M u$. circinelloides f. lusitanicus (CBS 108.17 and CBS 276.49) (Figure 5). The causal agent of charcoal rot was isolated in this study. Two representative isolates (CMML21-15 and CMML21-16) were sequenced with ITS and EF1- $\alpha$; the sequence and phylogenetic analyses revealed that the isolates were identified as M. phaseolina and matched well with the reference strains of M. phaseolina (CBS 277.33, CBS 162.25, and CPMM) (Figure 6).

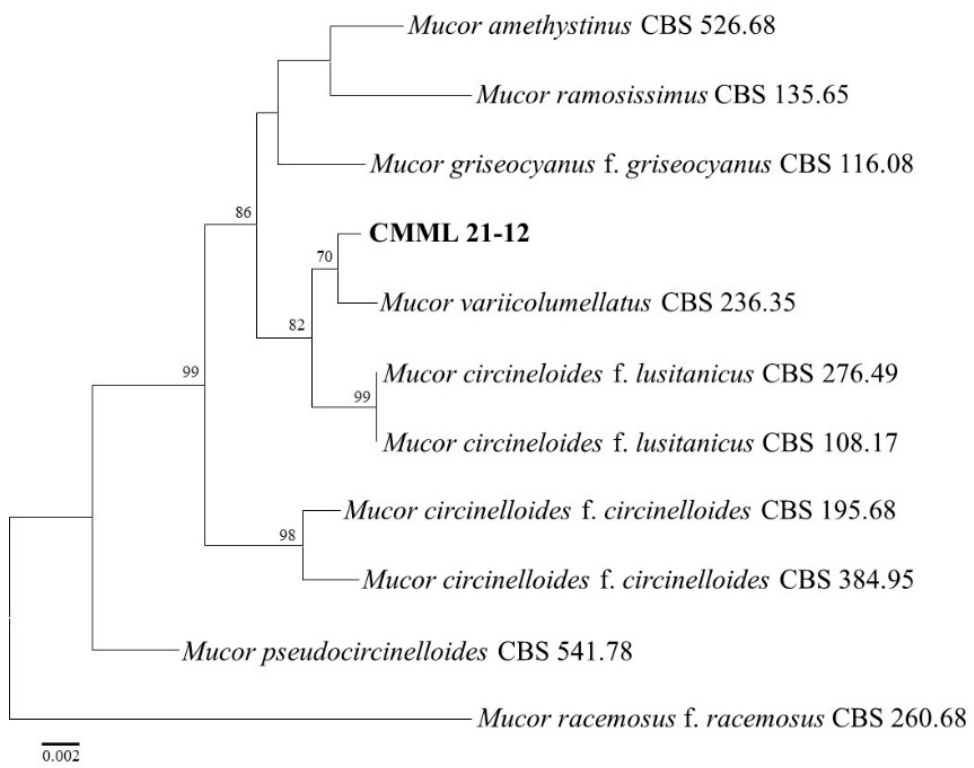

Figure 5. The maximum likelihood tree of the Mucor isolates (CMML21-12) was inferred from the combined datasets of the ITS, LSU, and SSU gene sequences constructed by the MEGA X program. The tree is rooted to $M u$. racemosus f. racemosus CBS 260.68. The number on branches indicates the bootstrap values. The scale bar indicates expected changes per site. The isolates from the present study are indicated in bold.

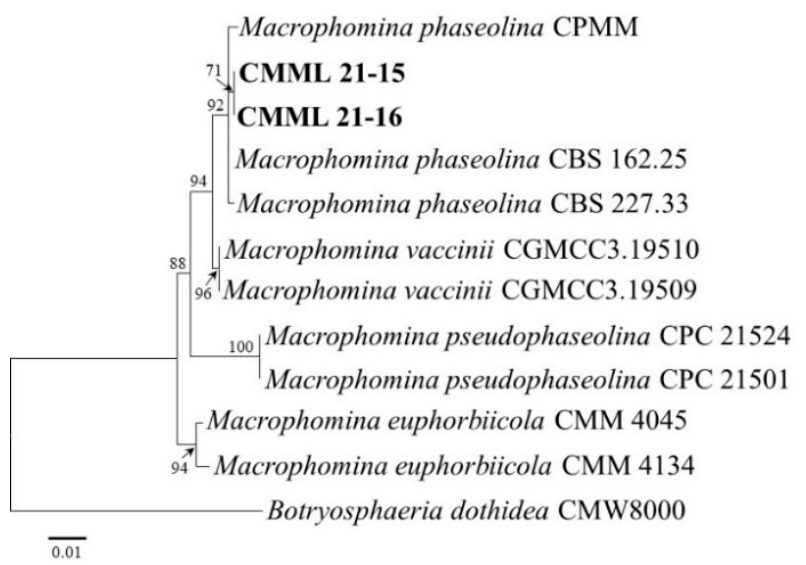

Figure 6. Maximum likelihood tree of the Macrophomina isolates (CMML21-15 and CMML21-16) inferred from the combined data sets of the ITS and EF1- $\alpha$ gene sequences constructed by the MEGA X program. The tree is rooted to Botryosphaeria dothidea CMW8000. Numbers on the branches indicate the bootstrap values. The scale bar indicates expected changes per site. The isolates from the present study are indicated in bold. 


\subsection{Morphology}

For morphological analysis, fungal isolates were grown on different media (mostly PDA and MEA) at $25{ }^{\circ} \mathrm{C}$ in darkness to facilitate colony morphology, texture, color, and the sizes and shapes of conidia and conidiophores. Representative isolates from Fusarium species to characterize morphologically were CMML21-2, CMML21-8, and CMML21-17. The size of the macro and microconidia of the isolate CMML21-2 ranged from $14.5-33.0 \times 2.7-4.4 \mu \mathrm{m}$ to $5.6-10.2 \times 2.5-3.8 \mu \mathrm{m}$ (Figure 7A). The macroconidia were slightly curved or straight, usually with three septations, and the microconidia were elliptical to cylindrical with no septation. Morphologically, the isolate CMML21-2 was identical to the previous descriptions of F. oxysporum [3].
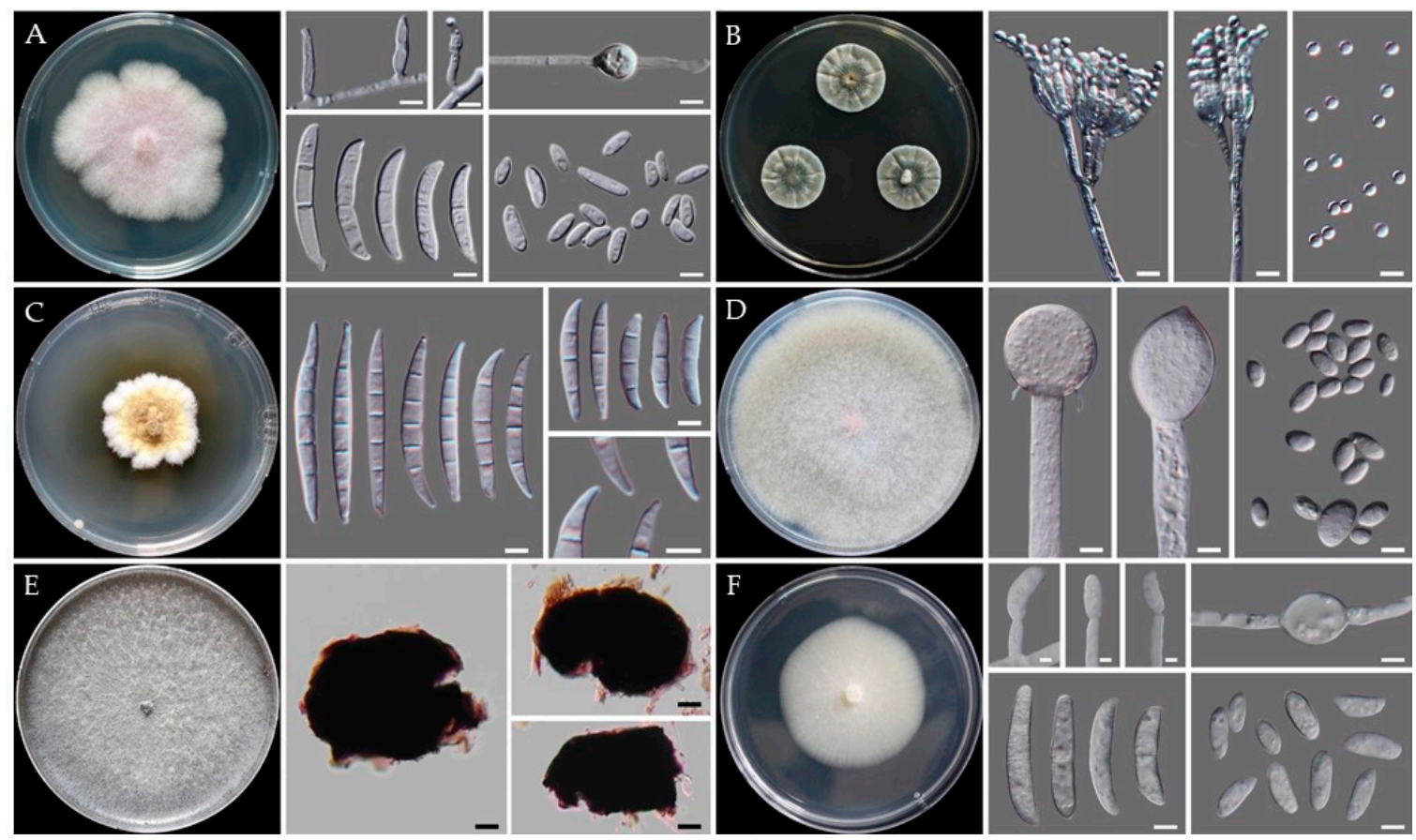

Figure 7. Morphological characteristics of representative isolates cultured on PDA or CYA for 7 days at $25{ }^{\circ} \mathrm{C}$. (A) F. oxysporum CMML21-2, colony on PDA, monophialides, chlamydospores, macro, and microconidia; (B) P. citrinum CMML21-5, colony on CYA, conidiophores and conidia; (C) F. ipomoeae CMML21-8, colony on PDA, macroconidia, and typical structures of conidial ends; (D) Mu. variicolumellatus CMML21-12, colony on PDA, sporangium, and multi sized spores; (E) M. phaseolina CMML21-15, colony on PDA with sclerotia; and (F) F. solani CMML21-17, a colony on PDA, monophialides, intercalary chlamydospores, macro and microconidia. Scale bars, $(\mathbf{A}-\mathbf{D}, \mathbf{F})=5 \mu \mathrm{m}$ and $(\mathbf{E})=10 \mu \mathrm{m}$.

Morphology study of the isolate CMML21-8 revealed that the colony on PDA after 7 days at $25{ }^{\circ} \mathrm{C}$ was white, fluffy, and grew moderately quickly; cotton-like aerial mycelia were common. Conidia formation was hard; conidia were slightly curved and tapered at the apex. Conidial size varied and ranged between $17.5-49.0 \times 3.1-5.6$ to $5.1-8.0 \times 3.1-4.7 \mu \mathrm{m}$, and 3-5 septations was common (Figure 7C). Microconidia were ovoid, single-celled, and non-septate, and the shapes were globose. Morphologically, the isolate was identical to the previously described F. ipomoeae [32-35]. The isolate CMML21-17 was grown on PDA for 7 days at $25^{\circ} \mathrm{C}$; the fungus produced sparse aerial mycelia, orange pigment on the agar, and whitish to off-white colonies. The macroconidia shape was cylindrical to falcate with rounded apical cells. The average length and width of the macroconidia were 10.5-30.6 $\times 4.1-5.7 \mu \mathrm{m}$, respectively. The septation of the conidial cells observed were one to four. The shape of the microconidia was fusiform to ovoid and varied in size with no or a rare single septation (Figure 7F). Based on the morphological and cultural characteristics, the fungal isolate was identified as F. solani [15]. 
The isolates CMML21-5 and CMML21-6 were identified as P. citrinum. CMML21-5 was cultured on MEA, CYA, and YES at $25^{\circ} \mathrm{C}$ for 7 days. The reverse colors on CYA and YES were brownish-yellow and yellow or orange yellow, respectively. The size of the colonies varied with the media; the diameters on MEA, CYA, and YES were 34-40, 25-28, and 23-26 mm, respectively. Conidia were globose to sub-globose with smooth walls (Figure 7B). Moderate sporulation on CYA with bluish gray green conidia. Moderate to good sporulation on YES and strong, soluble yellow pigment were produced. On MEA, strong blue, velvety with small pale yellow exudate droplets were produced. Conidiophores biverticillate or terverticillate and abundant on fresh isolates with smooth-walled stipes; metulae in whorls, ranging from 10.0-14.0 $\times 2.2-2.8 \mu \mathrm{m}$ in diameter; phialides ampuliform with sizes ranging from 6.4-9.1 $\times 1.6-2.2 \mu \mathrm{m}$. The isolates differed from relatives with yellow reverse on CYA, globose and smooth-walled conidia; sizes were 2.3-3.1 × 2.3-3.4 $\mu \mathrm{m}$. Morphological features matched well with previous explanations of P. citrinum [36].

The isolate CMML21-12 was identified by molecular methods as $\mathrm{Mu}$. variicolumellatus, which had previously been found in sweet potatoes [18]. The sporangia formed on repeatedly sympodially branched sporangiospores and were mostly two types of sporangiophores: short, intensive, sympodially branched and tall, less branched. The spores termed as sporangiospores were either subglobose and less than 15 (11.1-14.6) $\mu \mathrm{m}$ diameter or ellipsoidaland and less than 10 (4.2-9.1) $\mu \mathrm{m}$ diameter (Figure 7D). Based on its morphological characteristics, the species was identified as $M u$. variicolumellatus $[37,38]$.

Two isolates, CMML21-15 and CMML21-16, were isolated from the charcoal rot of the sweet potato. Morphologically, they were initially white but later became dark gray to blackish with many black, oblong microsclerotia on the PDA after culturing for 7 days at $25{ }^{\circ} \mathrm{C}$. Aggregation of hyphae formed jet black microsclerotia, 26.7-90.1 $\times 26.3-52.2 \mu \mathrm{m}$ in size. The microsclerotia were irregular in shape-some were round to oblong and smooth-walled (Figure 7E). These isolates were confirmed as M. phaseolina based on these explained characteristics [39-41].

\subsection{Taxonomy: Aspergillus wentii CMML21-4}

Isolates examined: CMML21-3 and CMML21-4.

Phylogeny: Three markers were used to identify the fungal species: ITS = OK104044-45, $\mathrm{BT}=\mathrm{OK} 104452-53$, and $\mathrm{CAL}=\mathrm{OK} 104457-58$. One more marker was used for sequencing: RPB2 $=$ OK104462-63. Sequence analysis and a phylogenetic tree revealed that the isolates CMML21-3 and CMML21-4 completely matched with A. wentii CBS 104.04 and CBS 118.34.

Morphology: On CYA at $25^{\circ} \mathrm{C}$ : After 7 days colony diameter was $32-35 \mathrm{~mm}$. Colonies white yellowish; exudates present; reverse ivory yellow to cream. Colonies radially furrowed, floccose (Figure 8A,D). On MEA at $25^{\circ} \mathrm{C}$, colonies white to yellow and reaching 23-26 $\mathrm{mm}$ in diameter, reverse light buff to light ochraceous salmon. Colony furrowed and floccose; conidia were splitting into loose narrow columns (Figure 8B,E). On YES at $25^{\circ} \mathrm{C}$ : Colonies white to white to yellow; furrowed, reverse yellowish and reaching $28-30 \mathrm{~mm}$ in diameter. Exudate present (Figure 8C,F).

Conidiophore's stipes smooth, hyaline to pale yellow brown; vesicles subglobose to globose or obovoid, ellipsoidal, 17.0-29.4 $\mu \mathrm{m}$ wide. Aspergilla biseriate, metulae covering $4 / 5$ of the whole surface of the vesicle, $4.8-24.3 \times 3.2-7.9 \mu \mathrm{m}$; phialides $6.7-8.5 \times 2.6-4.0 \mu \mathrm{m}$. Conidia varied in shape and size; globose to ellipsoidal or doliiform, and 3.7-6.9 $\mu \mathrm{m}$ in size (Figure 8G-I).

Distribution: A. wentii is found in many crops, including cotton seeds, barley, rice, olives, pineapples, oats, nuts, pecans, groundnuts, wheat, and fir. The fungi are not limited to plants and vegetables but have also been associated with indoor mold and rhizospheric soils. This is the first worldwide report of $A$. wentii-caused disease of postharvest sweet potato storage roots.

Note: This fungus has been found in many countries, including China, the USA, Japan, and India but here for the first time in Korea. 

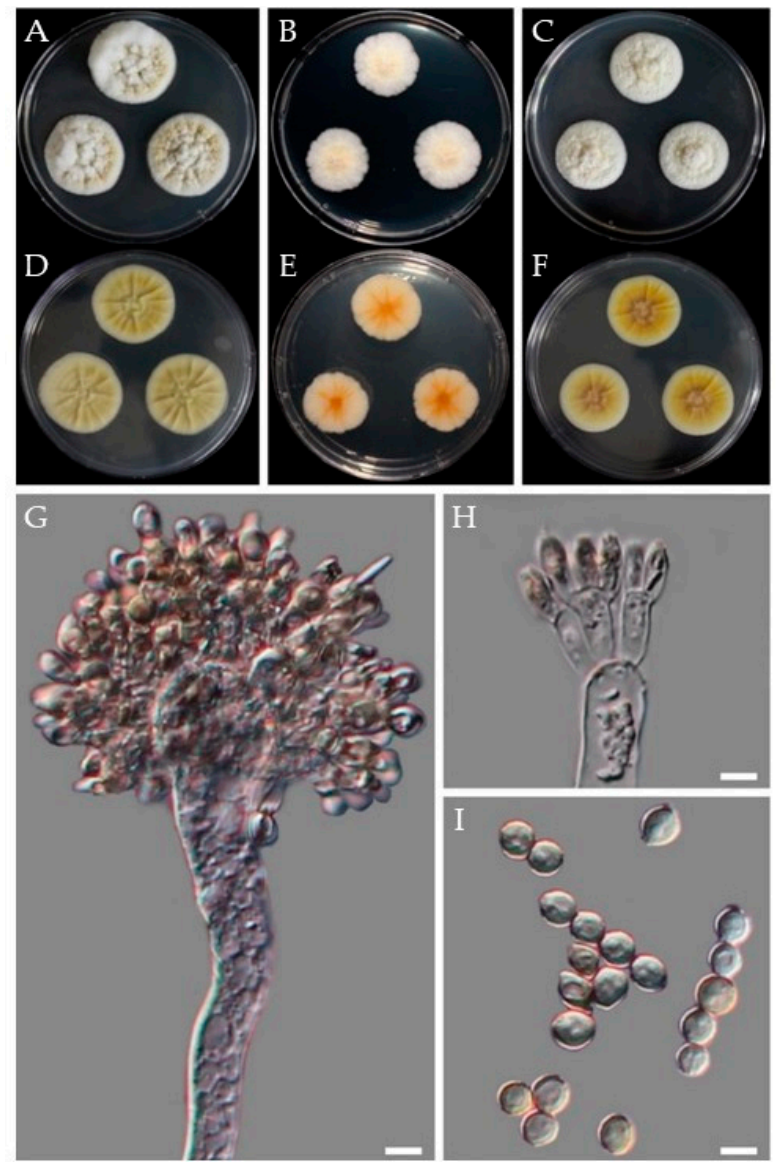

Figure 8. Morphological features of the isolate CMML21-4. Obverse and reverse colony morphology on CYA (A,D), MEA (B,E), and YES $(\mathbf{C}, \mathbf{F})$ after 7 days at $25^{\circ} \mathrm{C}$. Structures and shapes of conidiophores $(\mathbf{G}, \mathbf{H})$; conidia $(\mathbf{I})$. Scale bars, $(\mathbf{G}-\mathbf{I})=5 \mu \mathrm{m}$.

\subsection{Taxonomy: Penicillium rotoruae CMML21-7}

Phylogeny: Four markers were used to identify the fungal species: ITS $=$ OK104048, $\mathrm{BT}=\mathrm{OK} 104456, \mathrm{RBP} 2=\mathrm{OK} 104466$, and CAL $=\mathrm{OK} 104461$. Sequence analysis revealed that the isolate CMML21-7 matched completely with P. rotoruae CBS 145834. Relatives of the isolate are P. ochrochloron DTO 189-A6, CBS 357.48, and P. svalbardense CBS 122.41.

Morphology: On CYA at $25^{\circ} \mathrm{C}$ : After 7 days colony diameter was $58-60 \mathrm{~mm}$. Colonies off-white to pale primrose, smooth, deep radial furrows extending to sub-margin furrows with cracked ridges. No exudate was observed (Figure 9A,D). On MEA at $25^{\circ} \mathrm{C}$ : Colonies white to off-white and reaching $46-50 \mathrm{~mm}$ in diameter. A sub-margin was observed, slightly depressed and no obvious conidiogenesis (Figure 9B,E). On YES at $25^{\circ} \mathrm{C}$ : Colonies white to off-white and reaching $57-59 \mathrm{~mm}$ in diameter, smooth and velvety texture. No obvious conidiogenesis and reverse ochraceous salmon (Figure 9C,F).

Conidiophores are mostly monoverticilliate but occasionally divaricate or biverticilliate; stipes smooth-walled, rarely finely roughened. The sizes of the stipes were 31.0-150.5 × 3.2-3.6 $\mu \mathrm{m}$; metula 1-2 per stipe, 8.9-12.4 $\times 1.6-2.6 \mu \mathrm{m}$, phialides ampulliform, 5.1-8.7 $\times 1.7-2.3 \mu \mathrm{m}$. Conidia were subglobose to slightly ovoid and smooth-walled, 2.8-3.8 $\times 2.6-3.6$ (Figure 9G-K).

Distribution: The P. rotoruae was first described as a new species from in-ground timber in New Zealand [42]. This is the first worldwide report of P. rotoruae-caused disease in sweet potatoes.

Note: All four sequences matched well with the fungus P. rotoruae. This fungus exhibits relatively fast-growing colonies on CYA at $25^{\circ} \mathrm{C}$ but is slower than its relatives (P. ochrochloron and P. svalbardense). Conidiogenesis generally was not observed but was 
abundant at $30^{\circ} \mathrm{C}$. Stipes were smooth-walled and rarely roughened; conidia subglobose to slightly ovoid and smooth-walled.
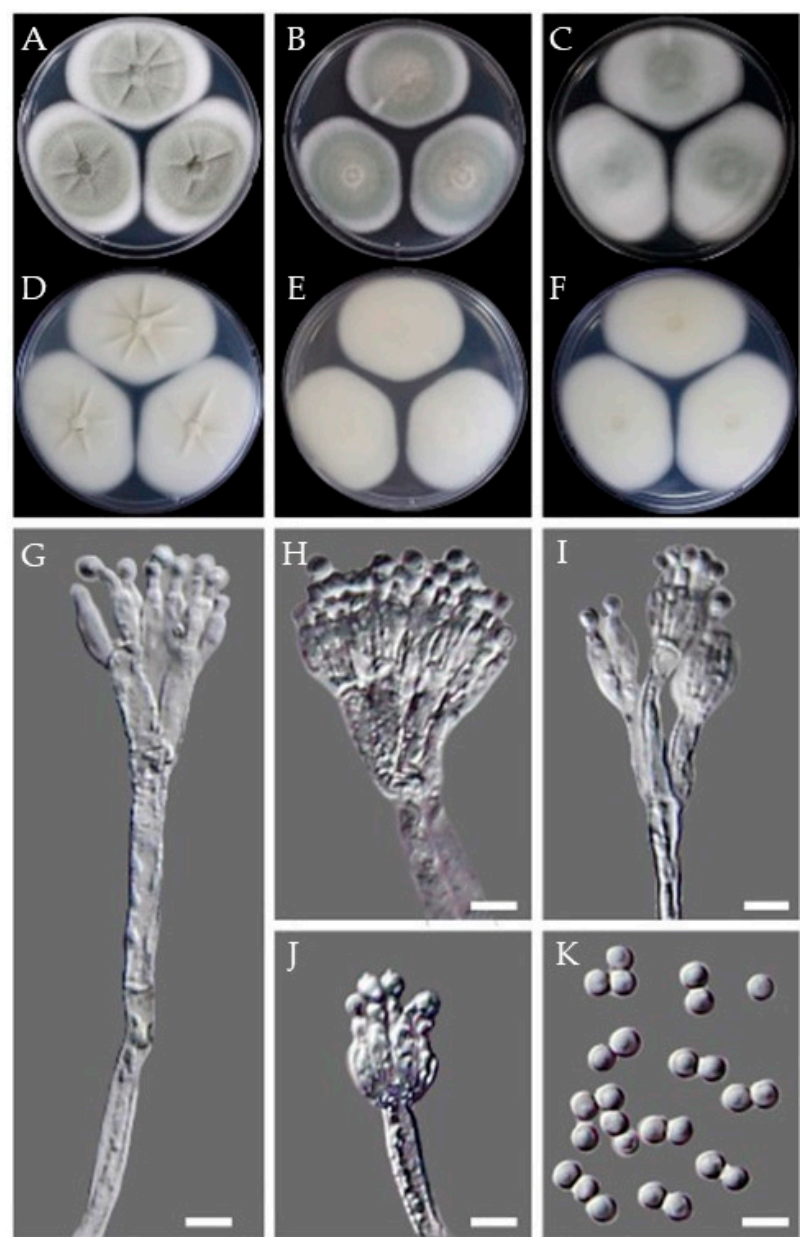

Figure 9. Morphological observations of the isolate CMML21-7. Obverse and reverse colony morphology on CYA (A,D), MEA (B,E), and YES (C,F) after 7 days at $25^{\circ} \mathrm{C}$. Structures and shapes of conidiophores including phialides, metulae, and stipes $(\mathbf{G}-\mathbf{J})$; conidia $(\mathbf{K})$. Scale bars, $(\mathbf{G}-\mathbf{K})=5 \mu \mathrm{m}$.

\subsection{Pathogenicity}

All the species were tested for pathogenicity. Each isolate was inoculated on the sweet potato variety 'Beniharuka'. Pathogenicity tests confirmed their disease-producing ability. After 3 weeks of infection, the result showed that the pathogens infected all the treated sweet potato storage roots and exhibited strong to mild pathogenicity. The virulence of the pathogen and isolates varied at a $5 \%$ level of significance $(p<0.05)$. The isolate CMML21-16, which was confirmed as M. phaseolina, showed the highest disease severity by producing charcoal rot disease on sweet potato storage roots. The average length and depth of lesions were 112.95 and $42.80 \mathrm{~mm}$, respectively (Table 2).

The least infected sweet potato was caused by the pathogen $M u$. variicolumellatus and the average lesion length and depth were 12.65 and $5.03 \mathrm{~mm}$, respectively. Among all the Fusarium species, F. ipomoeae CMML21-8 caused higher disease infection than the other two species F. oxysporum (CMML21-2 and CMML21-13) and F. solani (CMML21-17). The newly isolated pathogen $A$. wentii showed the lesion length and depth of 15.32 and $7.80 \mathrm{~mm}$, respectively. In addition, the average lesion length and depth caused by the pathogen P. rotoruae were 15.55 and $7.23 \mathrm{~mm}$, respectively, and the species caused higher lesion length and depth than P. citrinum (Table 2 and Figure 10). 
Table 2. The pathogenicity of the pathogenic species obtained in the present study in a sweet potato variety (Beniharuka) 3 weeks after surface wound inoculation.

\begin{tabular}{ccc}
\hline Fungal Isolates & Disease Length $\mathbf{( m m )}$ & Disease Depth $(\mathbf{m m})$ \\
\hline Fusarium oxysporum CMML21-2 & $13.52 \pm 0.95 \mathrm{c}$ & $6.67 \pm 1.92 \mathrm{~b}$ \\
Aspergillus wentii CMML21-4 & $15.32 \pm 0.61 \mathrm{c}$ & $7.80 \pm 0.95 \mathrm{~b}$ \\
Penicillium citrinum CMML21-5 & $12.96 \pm 1.02 \mathrm{c}$ & $6.20 \pm 0.66 \mathrm{~b}$ \\
Penicillium rotoruae CMML21-7 & $15.55 \pm 0.32 \mathrm{c}$ & $7.23 \pm 0.39 \mathrm{~b}$ \\
Fusarium ipomoeae CMML21-8 & $23.47 \pm 2.09 \mathrm{~b}$ & $9.30 \pm 1.11 \mathrm{~b}$ \\
Mucor variicolumellatus CMML21-12 & $12.65 \pm 0.58 \mathrm{c}$ & $5.03 \pm 1.47 \mathrm{~b}$ \\
Fusarium oxysporum CMML21-13 & $16.85 \pm 2.22 \mathrm{bc}$ & $9.27 \pm 1.13 \mathrm{~b}$ \\
Macrophomina phaseolina CMML21-16 & $112.95 \pm 2.25 \mathrm{a}$ & $42.80 \pm 0.30 \mathrm{a}$ \\
Fusarium solani CMML21-17 & $14.06 \pm 2.03 \mathrm{c}$ & $6.90 \pm 1.15 \mathrm{~b}$ \\
\hline
\end{tabular}

Note. Data of length on surface and depth of the disease spot in the table are the mean \pm SE. Different lowercase letters after data indicate significant differences among isolates $(p<0.05)$. Values with the same letters are not significantly different.

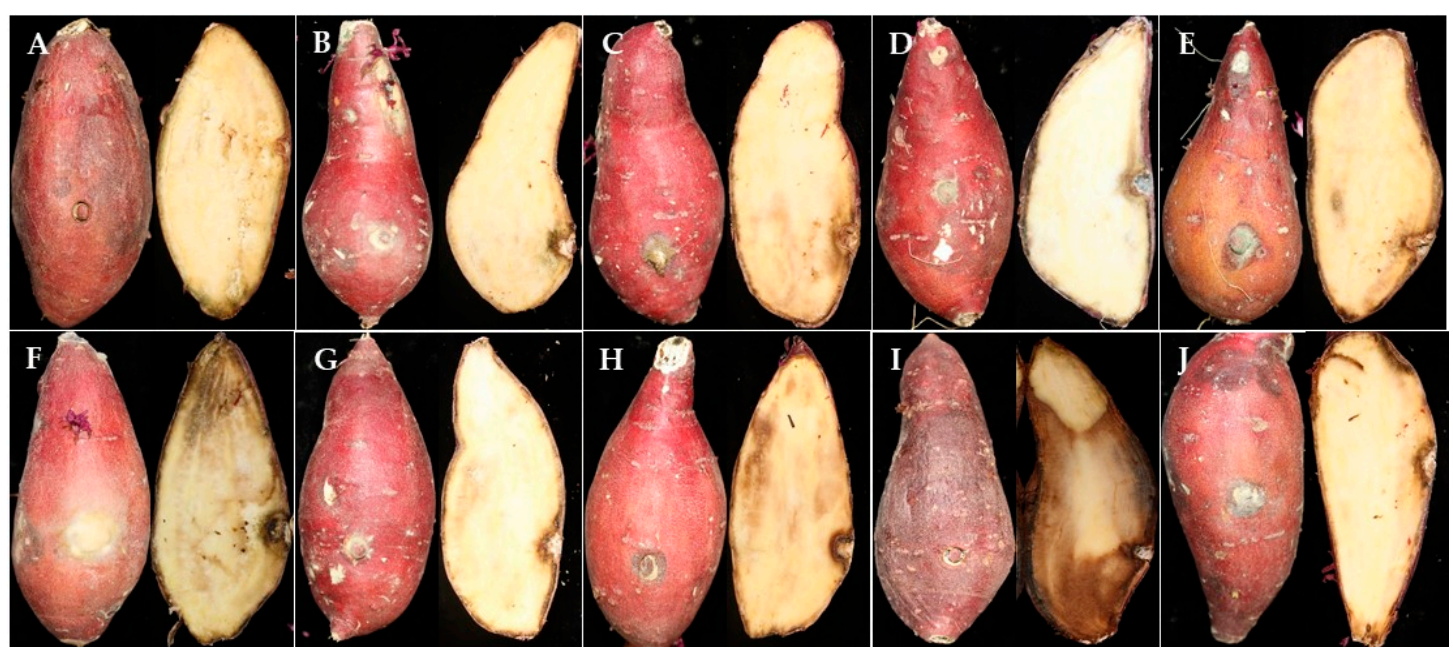

Figure 10. Pathogenicity tests of fungal isolates obtained from this study on the 'Beniharuka' variety. (A) control, (B) F. oxysporum CMML21-2, (C) A. wentii CMML21-4, (D) P. citrinum CMML21-5, (E) P. rotoruae CMML21-7, (F) F. ipomoeae CMML21-8, (G) Mu. variicolumellatus CMML21-12, (H) F. oxysporum CMML21-13, (I) M. phaseolina CMML21-15, (J) F. solani CMML21-17.

\subsection{In Vitro Antifungal Activity}

Two antagonistic T. harzianum strains (CMML20-26 and CMML20-27) were tested against eight different pathogenic species isolated from sweet potato storage roots. Dual culture activity results revealed that the two T. harzianum strains showed strong antifungal activity against all tested pathogens. Two Trichoderma strains showed strong antagonistic activity against $F$. oxysporum isolates (CMML21-2 and CMML21-13), and the rate of pathogen inhibition was $72.88-81.14 \%$. The newly recovered pathogen in sweet potato A. wentii (CMML21-4) was inhibited $73.93-77.04 \%$ by the two antagonists. Lower inhibition was observed against P. citrinum (CMML21-5) (Table 3). Another new disease-producing pathogen, P. rotoruae (CMML21-7), was inhibited by CMML20-26 and CMML20-27 by 69.40 and $58.13 \%$, respectively. The inhibition of F. ipomoeae (CMML21-8) by two T. harziaznum strains was $56.99-57.06 \%$. The lowest inhibition rate ( 42.66 to $50.21 \%$ ) was observed against $\mathrm{Mu}$. variicolumellatus (CMML21-12). The pathogen inhibition rate of M. phaseolina (CMML21-15) and F. solani (CMML21-17) was 75.01-78.22\% and 64.94-68.83\%, respectively, by these antagonistic fungal strains (Table 3 and Figure 11). 
Table 3. Antifungal activity of Trichoderma harzianum strains CMML20-26 and CMML20-27 against all the pathogenic species recovered in the present study.

\begin{tabular}{ccc}
\hline \multirow{2}{*}{ Fungal Isolates } & \multicolumn{2}{c}{ Inhibition Rate (\%) } \\
\cline { 2 - 3 } & CMML20-26 & CMML20-27 \\
\hline Fusarium oxysporum CMML21-2 & $81.14 \pm 3.07 \mathrm{a}$ & $72.05 \pm 0.92 \mathrm{ab}$ \\
Aspergillus wentii CMML21-4 & $77.04 \pm 0.69 \mathrm{abc}$ & $73.93 \pm 2.50 \mathrm{a}$ \\
Penicillium citrinum CMML21-5 & $53.87 \pm 2.04 \mathrm{~d}$ & $53.87 \pm 0.48 \mathrm{de}$ \\
Penicillium rotoruae CMML21-7 & $69.40 \pm 0.51 \mathrm{bc}$ & $58.13 \pm 1.35 \mathrm{~cd}$ \\
Fusarium ipomoea CMML21-8 & $56.99 \pm 3.44 \mathrm{~d}$ & $57.06 \pm 1.60 \mathrm{~cd}$ \\
Mucor variicolumellatus CMML21-12 & $50.21 \pm 1.27 \mathrm{~d}$ & $42.66 \pm 1.28 \mathrm{e}$ \\
Fusarium oxysporum CMML21-13 & $75.29 \pm 0.49 \mathrm{abc}$ & $72.88 \pm 2.99 \mathrm{ab}$ \\
Macrophomina phaseolina CMML21-16 & $78.22 \pm 0.91 \mathrm{ab}$ & $75.01 \pm 2.50 \mathrm{a}$ \\
Fusarium solani CMML21-17 & $68.83 \pm 0.89 \mathrm{c}$ & $64.94 \pm 0.65 \mathrm{bc}$
\end{tabular}

Note: Data of inhibition rate in the table are the mean \pm SE. Different lowercase letters after data indicate significant differences among strains $(p<0.05)$. Values with the same letters are not significantly different.

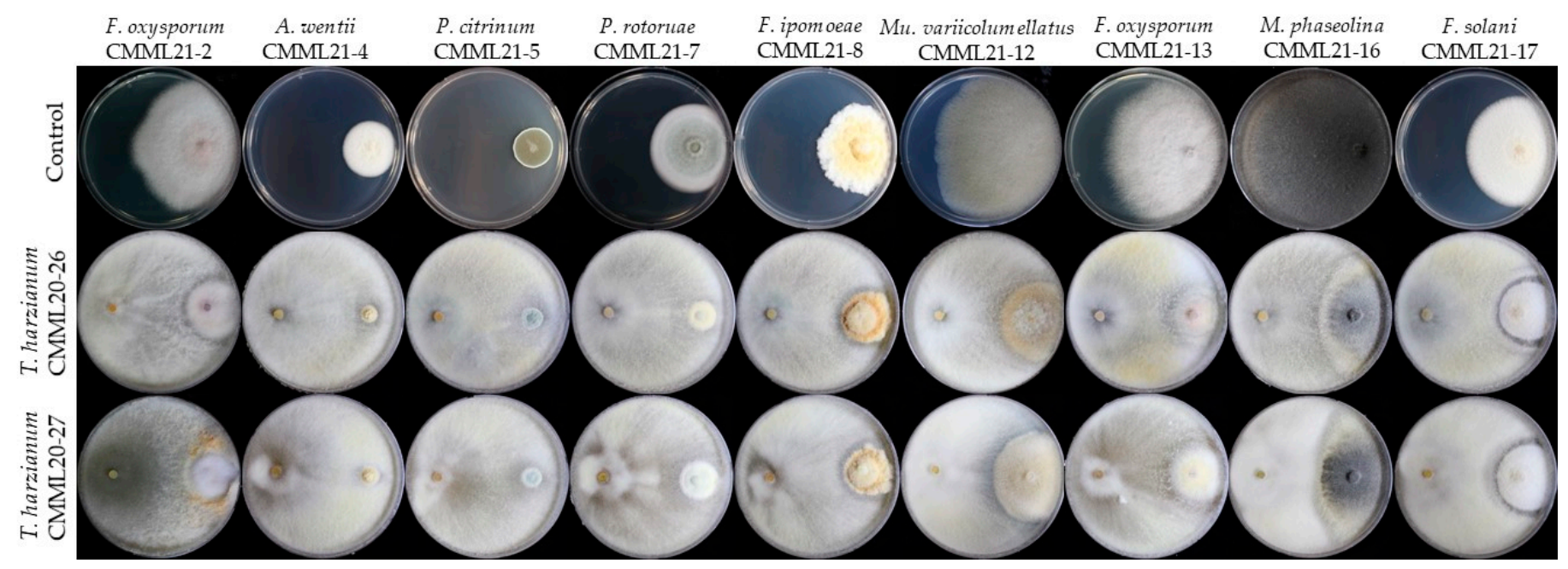

Figure 11. Representative photographs of in vitro dual culture assay for mycelial growth inhibition of 8 different pathogenic species isolated from sweet potato storage roots by Trichoderma harzianum strains CMML20-26 and CMML20-27.

\section{Discussion}

Sweet potato is the eleventh most important food crop globally [10] and is valuable in nutrition content. It contains high levels of carbohydrates and minerals as well as dietary fibers [3,6,37]. Sweet potato is popular in Korea, and the total area of sweet potato production has increased [3]. However, many common fungal diseases are reported worldwide during storage and marketing of this crop, such as Fusarium surface rot, Fusarium storage root rot and end rot, sclerotial circular spot, soft rot, black rot, blue mold, dry rot, and charcoal rot caused by Fusarium spp., F. solani, Sclerotium rolfsii, Rhizopus and Mucor spp., Penicillium spp., Diaporthe batatas, and M. phaseolina, respectively [3,6,10,15-17].

In the present study, surface rot, blue mold, and charcoal rot diseases were commonly observed, and F. oxysporum, F. ipomoeae, P. citrinum, and M. phaseolina were frequently isolated. The most frequent pathogen was F. oxysporum, which caused surface rot disease. The disease is more damaging than any other storage disease of sweet potato worldwide [3]. In addition, end rot and charcoal rot diseases were found in the study. Several fungal species caused end rot, including F. solani, M. phaseolina, Lasiodiplodia theobromae, and D. batatas [20]. F. solani was isolated from the end rot disease, and the M. phaseolina isolates were isolated from charcoal rot diseases. Charcoal rot of sweet potato is widespread in the tropics [43]; decay usually begins at the end of the storage roots. Initial symptoms are variously shaped and sized pale brown discolorations, and eventually, rotten roots with micro-sclerotia colonize interiorly. The Mucor sp. was isolated from rotten sweet potatoes. 
Multigene molecular phylogeny identified the pathogen as $M$. varricolumellatus, which Wagner named in 2020 [38]. Detailed description and the reference explanation showed that the pathogen belongs to the $\mathrm{Mu}$. circinelloides species complex group. $\mathrm{Mu}$. circinelloides (Syn. M. racemosus) was previously isolated as a pathogen from sweet potato [18].

The pathogenicity test is essential to observe the environmental condition producing the disease and whether the pathogen isolated was virulent or not and to confirm Koch's postulates. All the pathogens tested for pathogenicity in the present study showed disease symptoms in a different lesion length. The most severe disease was observed on sweet potato storage roots inoculated by the M. phaseolina isolate. Macrophomina spp. are the most severe and frequent species among fungal isolates recovered from sweet potato stems and storage roots with rot symptoms in Brazil [14]. M. phaseolina deserves to be highlighted as it is a widely distributed plant pathogen that can produce microsclerotia that survive in the soil for a long time [14,44]. The pathogenicity tests on storage roots showed disease symptoms, but the disease progression was slow, which is common in storage environments $[3,15,20]$. Pathogenicity and disease progression depend on many factors, including inoculum density, temperature, and their interactions [45]. Therefore, the degrees of pathogenicity varied with isolates and fungal species.

Two new postharvest disease pathogens, $A$. wentii and $P$. rotoruae, were isolated in the storage roots of sweet potato. A. wentii caused black mold or dry rot disease, and $P$. rotoruae caused blue mold disease. The pathogen $A$. niger causes black mold rot in storage roots and has been reported from Bangladesh, China, India, Nigeria, and the USA [46,47]. Mold disease is also a common postharvest disease caused by Penicillium spp. including P. oxalicum and P. citrinum [46-49]. The present study identified for the first time two pathogens reported to cause disease in sweet potato, and pathogenicity tests confirmed their disease-producing ability. P. rotoruae was discovered and described as a new species in New Zealand [42], and the Republic of Korea is the second country where this fungal species has been found.

Postharvest diseases are caused by several factors, such as low $\mathrm{pH}$, moisture content, nutritional composition, improper handling, and management of storage roots during harvest, transport, and marketing. Improper handling causes wounds in storage roots and allows pathogens to enter, thus infecting the storage roots. Fusarium spp., M. phaseolina, and many other postharvest pathogens enter in such a way [50]. Infested sweet potatoes can cause serious health issues, especially mold pathogens including Aspergillus spp. and Penicillium spp., which produce mycotoxins that can be lethal to humans [50]. Therefore, proper handling of sweet potato cultivation as well as investigation of possible biocontrol agents and methods are needed to minimize the fungus-mediated infections after harvest. Different species of Trichoderma have been used for postharvest biocontrol agents in crops such as papayas, strawberries, tomatoes, apples, pears, and bananas. Three Trichoderma species, T. asperellum, T. viride, and T. harzianum, showed strong antagonistic activities against different fungal pathogens [51]. The biocontrol agents Trichoderma spp. use various mechanisms against pathogens, including production of antifungal compounds, competition for nutrients, parasitism or inhibition of pathogens, antibiosis, and production of lytic enzymes [51,52]. In this study, we investigated T. harzianum strains CMML20-26 and CMML20-27 for dual culture antagonistic activity and observed that these two biocontrol agents could reduce the pathogenic fungal growth up to $85 \%$. A similar antagonistic agent $T$. asperellum was isolated as a pathogen from the sweet potato storage roots, which inhibited the growth of pathogens such as F. oxysporum, F. proliferatum, L. theobromae, and Rhizopus nigricans [12]. Therefore, more attention should be given to test alternative biocontrol systems to reduce diseases of sweet potato with Trichoderma spp. as well as other biocontrol agents.

Supplementary Materials: The following are available online at https: / www.mdpi.com/article / 10.3390 /jof7110927/s1, Table S1, List of fungal isolates from postharvest sweet potatoes in Korea and primers were used for identification of the isolates in this study. Table S2, List of fungal species, strain number, and GenBank accession numbers of sequences used in this study. 
Author Contributions: Conceptualization, H.S.; methodology, N.C.P., H.L., S.P. and J.G.L.; formal analysis, H.L. and S.P.; morphology, DIC photographs, microscopy and pathogenicity, H.L., N.C.P., S.P., J.G.L. and G.H.H.; writing-original draft preparation, N.C.P.; writing-review and editing, H.S. and H.K.; supervision, H.S.; project administration and funding acquisition, H.S., H.K. and G.H.H. All authors have read and agreed to the published version of the manuscript.

Funding: This study was supported by grants from the New Breeding Technologies Development Program (Project No. PJ01483603), Rural Development Administration and Korea Institute of Planning and Evaluation for Technology in Food, Agriculture, Forestry (IPET) through the Useful Agricultural Life Resources Industry Technology Development Program funded by the Ministry of Agriculture, Food and Rural Affairs (MAFRA) (318012-4), Republic of Korea. This study was also supported by IPET through Crop Viruses and Pests Response Industry Technology Development Program funded by the MAFRA (321099-3), Republic of Korea.

Institutional Review Board Statement: No human participants and/or animals were involved in this research content.

Informed Consent Statement: This manuscript has not been published or presented elsewhere in part or entirety and is not under consideration by another journal. We have read and understood your journal policies, and we believe that neither the manuscript nor the study violates any of these. All the authors have been personally and actively involved in substantive work leading to the manuscript and will hold themselves jointly and individually responsible for its content. All co-authors agreed to this submission.

Data Availability Statement: GenBank accession numbers for the microorganism's sequence will be available soon and accession numbers are OK104035-OK104051 for ITS, OK104467-OK104475 for EF1, OK104452-OK104456 for BT, OK104462-OK104466 for RPB2, OK175702 for LSU, and OK175704 for SSU.

Conflicts of Interest: The authors declare no conflict of interest.

\section{References}

1. Jiang, L.; Jeong, J.C.; Lee, J.-S.; Park, J.M.; Yang, J.-W.; Lee, M.H.; Choi, S.H.; Kim, C.Y.; Kim, D.-H.; Kim, S.W.; et al. Potential of Pantoea dispersa as an Effective Biocontrol Agent for Black Rot in Sweet Potato. Sci. Rep. 2019, 9, 16354. [CrossRef] [PubMed]

2. Nedunchezhiyan, M.; Byju, G.; Jata, S.K. Sweet Potato Agronomy. Fruit Veg. Sereal Sci. Biotechnol. 2012, 6, 1-10.

3. Paul, N.C.; Park, W.; Lee, S.; Chung, M.N.; Lee, H.-U.; Yang, J.-W. Occurrence of Sweetpotato (Ipomoea batatas) Wilt and Surface Rot Disease and Determining Resistance of Selected Varieties to the Pathogen in Korea. Plants 2020, 9, 497. [CrossRef] [PubMed]

4. Wang, C.-J.; Wang, Y.-Z.; Chu, Z.-H.; Wang, P.-S.; Liu, B.-Y.; Li, B.-Y.; Yu, X.-L.; Luan, B.-H. Endophytic Bacillus Amyloliquefaciens YTB1407 Elicits Resistance against Two Fungal Pathogens in Sweet Potato (Ipomoea batatas (L.) Lam.). J. Plant Physiol. 2020, 253, 153260. [CrossRef]

5. Sugri, I.; Maalekuu, B.K.; Gaveh, E.; Kusi, F.; Lamini, S. Assessment of Low-Cost Postharvest Techniques to Reduce Storage Losses in Sweet Potato. Sustain. Agric. Res. 2020, 9, 17. [CrossRef]

6. Clark, C.A.; Moyer, J.W. Black rot. In Compendium of Sweetpotato Diseases, Pests, and Disorders; APS Press: St. Paul, MN, USA, 2013; pp. 29-33.

7. Sun, Y.; Li, M.; Wang, Y.; Li, L.; Wang, M.; Li, X.; Xu, M.; Loake, G.J.; Guo, M.; Jiang, J. Ceratocystis fimbriata Employs a Unique Infection Strategy Targeting Peltate Glandular Trichomes of Sweetpotato (Ipomoea batatas) Plants. Phytopathology ${ }^{\circledR}$ 2020, 110, 1923-1933. [CrossRef]

8. Bovell-Benjamin, A.C. Sweet Potato: A Review of its Past, Present, and Future Role in Human Nutrition. In Advances in Food and Nutrition Research; Elsevier B.V.: Amsterdam, The Netherlands, 2007; Volume 52, pp. 1-59. ISBN 978-0-12-373711-3.

9. El Sheikha, A.F.; Ray, R.C. Potential Impacts of Bioprocessing of Sweet Potato: Review. Crit. Rev. Food Sci. Nutr. 2017, 57, 455-471. [CrossRef]

10. Paul, N.C.; Nam, S.-S.; Kachroo, A.; Kim, Y.-H.; Yang, J.-W. Characterization and Pathogenicity of Sweet Potato (Ipomoea batatas) Black Rot Caused by Ceratocystis fimbriata in Korea. Eur. J. Plant Pathol. 2018, 152, 833-840. [CrossRef]

11. Scruggs, A.C.; Quesada-Ocampo, L.M. Etiology and Epidemiological Conditions Promoting Fusarium Root Rot in Sweetpotato. Phytopathology ${ }^{\circledR}$ 2016, 106, 909-919. [CrossRef]

12. Yang, Y.; Fang, B.; Feng, S.; Wang, Z.; Luo, Z.; Yao, Z.; Zou, H.; Huang, L. Isolation and Identification of Trichoderma asperellum, the Novel Causal Agent of Green Mold Disease in Sweetpotato. Plant Dis. 2021, 105, 1711-1718. [CrossRef]

13. Dania, V.O.; Thomas, A.S. Bioactivity and Phytochemical Composition of Moringa Oleifera in the Management of Fungal Rot Disease of Orange-Fleshed Sweetpotato. Niger. J. Mycol. 2019, 11, $26-45$. 
14. Mello, J.F.; Brito, A.C.Q.; Vieira, J.C.B.; Câmara, M.P.S.; Michereff, S.J.; Souza-Motta, C.M.; Machado, A.R. Identification and Pathogenicity of Botryosphaeriaceae Species Associated with Root and Stem Rot of Sweet Potato in Brazil. Plant Pathol. 2021, 70, 1601-1615. [CrossRef]

15. Yang, J.-W.; Nam, S.-S.; Lee, H.-U.; Choi, K.-H.; Hwang, S.-G.; Paul, N.C. Fusarium Root Rot Caused by Fusarium solani on Sweet Potato (Ipomoea batatas) in South Korea. Can. J. Plant Pathol. 2018, 40, 90-95. [CrossRef]

16. Paul, N.C.; Hwang, E.-J.; Nam, S.-S.; Lee, H.-U.; Lee, J.-S.; Yu, G.-D.; Kang, Y.-G.; Lee, K.-B.; Go, S.; Yang, J.-W. Phylogenetic Placement and Morphological Characterization of Sclerotium rolfsii (Teleomorph: Athelia rolfsii) Associated with Blight Disease of Ipomoea batatas in Korea. Mycobiology 2017, 45, 129-138. [CrossRef]

17. Loebenstein, G.; Thottappilly, G. The Sweet Potato; Springer: Dordrecht, The Netherlands, 2009.

18. Harter, L.L.; Weimer, J.L.; Adams, J.M.R. Sweet Potato Storage Rots. J. Agric. Res. 1918, 15, 337-368.

19. Arancibia, R.A.; Main, J.L.; Clark, C.A. Sweetpotato Tip Rot Incidence Is Increased by Preharvest Applications of Ethephon and Reduced by Curing. Hortte 2013, 23, 288-293. [CrossRef]

20. Da Silva, W.L.; Clark, C.A. Infection of Sweetpotato by Fusarium solani and Macrophomina phaseolina Prior to Harvest. Plant Dis. 2013, 97, 1636-1644. [CrossRef]

21. Yuan, B.; Xue, L.; Zhang, Q.; Kong, W.; Peng, J.; Kou, M.; Jiang, J. Essential Oil from Sweet Potato Vines, a Potential New Natural Preservative, and an Antioxidant on Sweet Potato Tubers: Assessment of the Activity and the Constitution. J. Agric. Food Chem. 2016, 64, 7481-7491. [CrossRef] [PubMed]

22. Hopfer, H.; Buffon, P.A.; Ebeler, S.E.; Heymann, H. The Combined Effects of Storage Temperature and Packaging on the Sensory, Chemical, and Physical Properties of a Cabernet Sauvignon Wine. J. Agric. Food Chem. 2013, 61, 3320-3334. [CrossRef] [PubMed]

23. Ji, S.H.; Paul, N.C.; Deng, J.X.; Kim, Y.S.; Yun, B.-S.; Yu, S.H. Biocontrol Activity of Bacillus amyloliquefaciens CNU114001 against Fungal Plant Diseases. Mycobiology 2013, 41, 234-242. [CrossRef] [PubMed]

24. Cubero, O.F.; Crespo, A.; Fatehi, J.; Bridge, P.D. DNA Extraction and PCR Amplification Method Suitable for Fresh, HerbariumStored, Lichenized, and Other Fungi. Plant Syst. Evol. 1999, 216, 243-249. [CrossRef]

25. Staats, M. Molecular Phylogeny of the Plant Pathogenic Genus Botrytis and the Evolution of Host Specificity. Mol. Biol. Evol. 2004, 22, 333-346. [CrossRef] [PubMed]

26. Aveskamp, M.M.; Verkley, G.J.M.; de Gruyter, J.; Murace, M.A.; Perelló, A.; Woudenberg, J.H.C.; Groenewald, J.Z.; Crous, P.W. DNA Phylogeny Reveals Polyphyly of Phoma Section Peyronellaea and Multiple Taxonomic Novelties. Mycologia 2009, 101, 363-382. [CrossRef]

27. Kumar, S.; Stecher, G.; Li, M.; Knyaz, C.; Tamura, K. MEGA X: Molecular Evolutionary Genetics Analysis across Computing Platforms. Mol. Biol. Evol. 2018, 35, 1547-1549. [CrossRef] [PubMed]

28. Thompson, J.D.; Gibson, T.J.; Plewniak, F.; Jeanmougin, F.; Higgins, D.G. The CLUSTAL_X Windows Interface: Flexible Strategies for Multiple Sequence Alignment Aided by Quality Analysis Tools. Nucleic Acids Res. 1997, 25, 4876-4882. [CrossRef]

29. Hall, T.A. BioEdit: A User-Friendly Biological Sequence Alignment Editor and Analysis Program for Windows95/98/NT. Nucleic Acids Symp. Ser. 1999, 41, 95-98.

30. Chilvers, M.I.; Jones, S.; Meleca, J.; Peever, T.L.; Pethybridge, S.J.; Hay, F.S. Characterization of Mating Type Genes Supports the Hypothesis that Stagonosporopsis chrysanthemi is Homothallic and Provides Evidence That Stagonosporopsis tanaceti is Heterothallic. Curr. Genet. 2014, 60, 295-302. [CrossRef]

31. Rayner, R.W. A Mycological Colour Chart; Commonwealth Mycological Institute: Surrey, UK, 1970.

32. Wonglom, P.; Sunpapao, A. Fusarium incarnatum Is Associated with Postharvest Fruit Rot of Muskmelon (Cucumis melo). J. Phytopathol. 2020, 168, 204-210. [CrossRef]

33. Wang, M.M.; Chen, Q.; Diao, Y.Z.; Duan, W.J.; Cai, L. Fusarium incarnatum-equiseti Complex from China. Persoonia 2019, 43, 70-89. [CrossRef]

34. Avila, C.F.; Moreira, G.M.; Nicolli, C.P.; Gomes, L.B.; Abreu, L.M.; Pfenning, L.H.; Haidukowski, M.; Moretti, A.; Logrieco, A.; Del Ponte, E.M. Fusarium incarnatum-equiseti Species Complex Associated with Brazilian Rice: Phylogeny, Morphology and Toxigenic Potential. Int. J. Food Microbiol. 2019, 306, 108267. [CrossRef] [PubMed]

35. Xia, J.W.; Sandoval-Denis, M.; Crous, P.W.; Zhang, X.G.; Lombard, L. Numbers to Names-Restyling the Fusarium incarnatumequiseti Species Complex. Persoonia 2019, 43, 186-221. [CrossRef]

36. Houbraken, J.A.M.P.; Frisvad, J.C.; Samson, R.A. Taxonomy of Penicillium citrinum and Related Species. Fungal Div. 2010, 44, 117-133. [CrossRef]

37. Lubbehusen, T.L.; Nielsen, J.; McIntyre, M. Characterization of the Mucor circinelloides Life Cycle by On-Line Image Analysis. J. Appl. Microbiol. 2003, 95, 1152-1160. [CrossRef] [PubMed]

38. Wagner, L.; Stielow, J.B.; de Hoog, G.S.; Bensch, K.; Schwartze, V.U.; Voigt, K.; Alastruey-Izquierdo, A.; Kurzai, O.; Walther, G. A New Species Concept for the Clinically Relevant Mucor circinelloides Complex. Persoonia 2020, 44, 67-97. [CrossRef] [PubMed]

39. Meena, R.P.; Kadam, V.A. Characterization of Macrophomina phaseolina Associated with Leaf Blight Disease on Chlorophytum borivilianum Santapau \& R.R. Fern. and Its Fungicidal Susceptibility. J. Appl. Res. Med. Aromat. Plants 2021, 20, 100288. [CrossRef]

40. Pandey, A.K.; Burlakoti, R.R.; Rathore, A.; Nair, R.M. Morphological and Molecular Characterization of Macrophomina phaseolina Isolated from Three Legume Crops and Evaluation of Mungbean Genotypes for Resistance to Dry Root Rot. Crop Prot. 2020, 127, 104962. [CrossRef] 
41. Popović, T.; Blagojević, J.; Aleksić, G.; Jelušić, A.; Krnjajić, S.; Milovanović, P. A Blight Disease on Highbush Blueberry Associated with Macrophomina phaseolina in Serbia. Can. J. Plant Pathol. 2018, 40, 121-127. [CrossRef]

42. O'Callahan, D.; Vaidya, A.; Donaldson, L.; Singh, T. Penicillium rotoruae, a New Species from an In-Ground Timber Durability Test Site in New Zealand. Curr. Microbiol. 2020, 77, 4129-4139. [CrossRef]

43. Ray, R.C.; Ravi, V. Post Harvest Spoilage of Sweetpotato in Tropics and Control Measures. Crit. Rev. Food Sci. Nutr. 2005, 45, 623-644. [CrossRef]

44. Sarr, M.P.; Ndiaye, M.; Groenewald, J.Z.; Crous, P.W. Genetic Diversity in Macrophomina phaseolina, the Causal Agent of Charcoal Rot. Phytopathol. Mediterr. 2014, 53, 250-268.

45. Stahr, M.; Quesada-Ocampo, L.M. Assessing the Role of Temperature, Inoculum Density, and Wounding on Disease Progression of the Fungal Pathogen Ceratocystis fimbriata Causing Black Rot in Sweetpotato. Plant Dis. 2020, 104, 930-937. [CrossRef]

46. Ray, R.C.; Byju, G. Root Surface Culturable Microflora Associated with Post Harvest Spoilage of Sweet Potato (Ipomoea batatas L.). Adv. Hortic. Sci. 2003, 17, 176-180.

47. Okungbowa, F.I.; Osagie, M. Mycoflora of Sun-Dried Sweet Potato (Ipomoea batatas L.) Slices in Benin City, Nigeria. Afr. J. Biotechnol. 2009, 8, 3326-3331.

48. Dayal, T.R.; Scott, G.J.; Kurup, G.T.; Balagopalan, C. Sweetpotato in South Asia: Postharvest Handling, Storage, Processing, and Use; Revised Edition; International Potato Center: Lima, Peru, 1991; ISBN 92-9060-180-9.

49. Zhang, L.; Zhao, L.; Bian, X.; Guo, K.; Zhou, L.; Wei, C. Characterization and Comparative Study of Starches from Seven Purple Sweet Potatoes. Food Hydrocoll. 2018, 80, 168-176. [CrossRef]

50. Agu, K.C.; Nweke, G.U.; Okeke, B.C.; Mgbemena, I.C.C.; Okigbo, R.N.; Ngenegbo, U.C. Fungi Associated with the Post-Harvest Loss of Sweet Potato. Int. J. Res. Stud. Biosci. 2015, 3, 33-38.

51. González-Estrada, R.; Blancas-Benítez, F.; Montaño-Leyva, B.; Moreno-Hernández, C.; Del Carmen Romero-Islas, L.; Romero-Islas, J.; Avila-Peña, R.; Ramos-Guerrero, A.; Fonseca-Cantabrana, A.; Gutierrez-Martinez, P.; et al. A Review Study on the Postharvest Decay Control of Fruit by Trichoderma. In Trichoderma-The Most Widely Used Fungicide; Manjur Shah, M., Sharif, U., Rufai Buhari, T., Eds.; IntechOpen: Lodnon, UK, 2019; ISBN 978-1-78923-917-1.

52. Marra, R.; Ambrosino, P.; Carbone, V.; Vinale, F.; Woo, S.L.; Ruocco, M.; Ciliento, R.; Lanzuise, S.; Ferraioli, S.; Soriente, I.; et al. Study of the Three-Way Interaction between Trichoderma atroviride, Plant and Fungal Pathogens by Using a Proteomic Approach. Curr. Genet. 2006, 50, 307-321. [CrossRef] 